\title{
A scrutiny study on wave energy potential and policy in TURKEY Muhammet Kaan YEŞILIUURT ${ }^{1}$, İlhan Volkan ÖNER ${ }^{1}$, Gökhan ÖMEROĞLU²*, Efe Çetin YILMAZ ${ }^{3}$ \\ ${ }^{1}$ Ataturk University Pasinler Vocational School, Department of Electricity and Energy \\ ${ }^{2}$ Ataturk University Engineering Faculty, Department of Mechanical Engineering \\ ${ }^{3}$ Ataturk University Pasinler Vocational School, Department of Electronics and Automation
}

\section{Article Info}

\section{Article history:}

Received May $26^{\text {th }}, 2017$

Revised Aug 20 $0^{\text {th }}, 2017$

Accepted Oct $18^{\text {th }}, 2017$

\section{Keyword:}

Electricity generation from wave energy, Wave energy, Wave energy potential in Turkey

\begin{abstract}
Recently new and renewable energy sources began to become prominent as alternatives to fossil fuels. Among these are wind, solar, hydraulic, biomass, geothermal and wave energies. As for Turkey, the least accounted and less applied of these sources is wave energy. The government has established a short-term outlook on utilization of renewable energy sources, named "National Renewable Energy Action Plan" which is a part of Vision 2023 targets. Nonetheless, there is no planned utilization of and/or investment into wave energy in Turkey's agenda up to the year 2023. This might be mainly because of the complex structure of wave energy conversion systems, marine conditions, mechanical difficulties and high initial investment costs. However, this type of energy is environmentally friendly, cheap and clean, and a great potential is available especially in Turkey which is surrounded on three sides by sea. Although Turkey has neither coasts to oceans nor a long stretch of west coastline, which have the highest energetic waves thanks to the prevailing west-to-east winds; the Black Sea basin, as well as the southwestern Mediterranean region, may offer a good potential for development as an energetic regime, often comparable to oceanic sites in terms of wave heights, induced by strong wind patterns. In this study, wave energy potential in Turkey and recent studies made on determination of suitable sites for evaluation of wave energy in Turkey are discussed.
\end{abstract}

\section{Corresponding Author:}

Third Author,

Engineering Faculty, Department of Mechanical Engineering Ataturk University 25200 Erzurum, Turkey

Email: gomeroglu@atauni.edu.tr 


\section{Introduction}

The total theoretical potential of renewable is huge, insomuch that it is deemed to be infinite when compared to the total energy need of man, which is around $12 \mathrm{TW} \max [1]$. Wave energy is not one of the richest, or the most prominent among renewable. For certain areas, it has a considerable potential. Why Turkey is not one of these areas, while it is surrounded by sea on three sides. One of the objectives of this study is to seek an answer to this question.

Wave energy, actually, is the buoyant force of the water together with the kinetic energy of the moving water column, which can be regarded as a concentrated form of wind energy generated by wind blowing over the ocean surface. Wave energy can be regarded as a concentrated form of wind energy generated by wind blowing over the ocean surface [2]. But when considered in terms of earth's energy balance, wave power is a byproduct of wind power, which is in turn a minor byproduct of solar power [3]. The net power transferred from wind to waves is seldom as much as $1 \mathrm{~W} / \mathrm{m}^{2}$, however, waves are far more powerful.

Wave energy and extracting energy from waves attracted a great deal of attention recently. But this is not a new phenomenon. The first patent dates back to 1799[4]. The oil crisis of the 1970s led to greater interest in utilization from waves and researches on concepts and technologies have been being carried out since then [5].Finally, it led to the world's first commercial wave farm (2.25 MW) built in 2005 in Portugal.

Wave energy is deemed to be one of the renewable energy sources with the greatest potential for development in the near future [6].

Reviews by [7] and [8] have shown that there are numerous projects at different stages of development. A number of pilot and demonstration projects, serving as research and development or proof of concept, applied around the world counts up to hundreds, with few contributing electricity to local grids.

\section{Wave Energy}

Oceans, which may be regarded as the largest solar collectors in the world, cover more than 70 percent of the surface of earth. Besides being that huge, they are the untapped and uninterrupted energy supply on the planet. The power density of wave energy is much higher than that of wind or solar energy. The environmental concerns in the use of wave systems for electricity generation are also less[4]. Marine based energy potential in the World is almost one fourth of wind energy and is more than those of hydraulic and biomass energies [9].

Oceans present innumerous benefits but in terms of energy harvesting, they might be seen as a non-stop machine that generate mechanical energy. Electricity generation is possible by capturing the energy of ocean waves by means of oscillating water columns, oscillating body converters or overtopping converters. Trapped air pockets in a water column, up-down, forwards-backwards or side to side wave motions as well as reservoirs to create a head can be utilized to drive turbines. Energy from each of the aforementioned can be converted into pneumatic/mechanical energy as rotation or translation force. Structures and positioning within the ocean may vary. Fixed, floating, submerged systems can be installed at shoreline, near shore or off shore [10].

Wave energy potential is estimated based on certain assumptions and these assumptions are always open to discussion. In order to make a more realistic determination, years-lasting and quite costly measurements are needed in the target region. Considering time and cost, in lieu of these measurements, more economical wind measurements are made and using empirical formulas, obtained from previously made researches, which gives the relationship between wind energy and wave energy can be used to estimate wave energy potential. Thus, 
the amount of electrical energy that can be obtained can be determined according to the number and specifications of WECS to be positioned at that measuring location [9].

\section{Wave Energy Technologies}

As can be seen in Fig. 1, there are different approaches and solutions to extract and absorb the energy of ocean waves developed considering different conditions and potentials such as the water depth and installation location $[11,7]$.

In this regard, devices can be categorized for many aspects. Location wise categorization can be made as shoreline, near shore (adapted into the shore), and offshore (away from the shore and in open sea). For wave energy conversion, channel/reservoir/turbine and air-driven turbine methods are applied [4].Another categorization is made according to what characteristics the harvesting system makes use of. In this regards systems are designed to make use of:

- the salinity difference between the surface waters and deep waters,

- mechanical energy of the tides,

- buoyant force or kinetic energy of the waves,

- or water streams [12].

It is better to consider and take advantage of the power that emerges between the buoyant force of the waves and water and gravity, rather than the kinetic energy that varies depending on many parameters [5].

According to how they are put in place, they might be grouped as fixed, submerged, floating, isolated, inbreakwater, rotating (or hinged), shoreline etc. With regards to how they interact with the water column, we can classify WECs as Oscillating Water Column (OWC), Oscillation Bodies (OB) and Overtopping (OT). Each system has various advantages and disadvantages. For instance, while land installed systems are easier to construct and maintain, there may be few locations suitable to install an OWC system. Likewise, while shoreline wave devices are advantageous in terms of installation and maintenance, energy potential is lower compared to other schemes. Near shore devices are positioned in shallow waters $(<20 \mathrm{~m})$ while offshore devices are more typical in deep waters (>40 m) [4].

Although there is an interest for Wave Energy applications, and in many countries community and government support for wave energy projects has raised in parallel to technological development in wave energy converters (WECs) which achieved a big growth recently[13,14], there is also a big handicap; cost.

Therefore, many technologies and approaches are far from being commercial and affordable because of the high cost of deployment. Full commercial Wave Energy Conversion systems (WECs) require more effort and research on the basic components to represent a solution that accelerates wave technology development by reducing costs and increase the performance [10].

Hybrid or multiplatform concepts seem to represent a solution. Platforms to combine wave energy technologies with offshore wind turbines or with aquaculture farms are considered to cast a solution for making wave energy more affordable by sharing foundation system costs, lowering operation and management costs as well as providing environmental benefits[15,1]. 


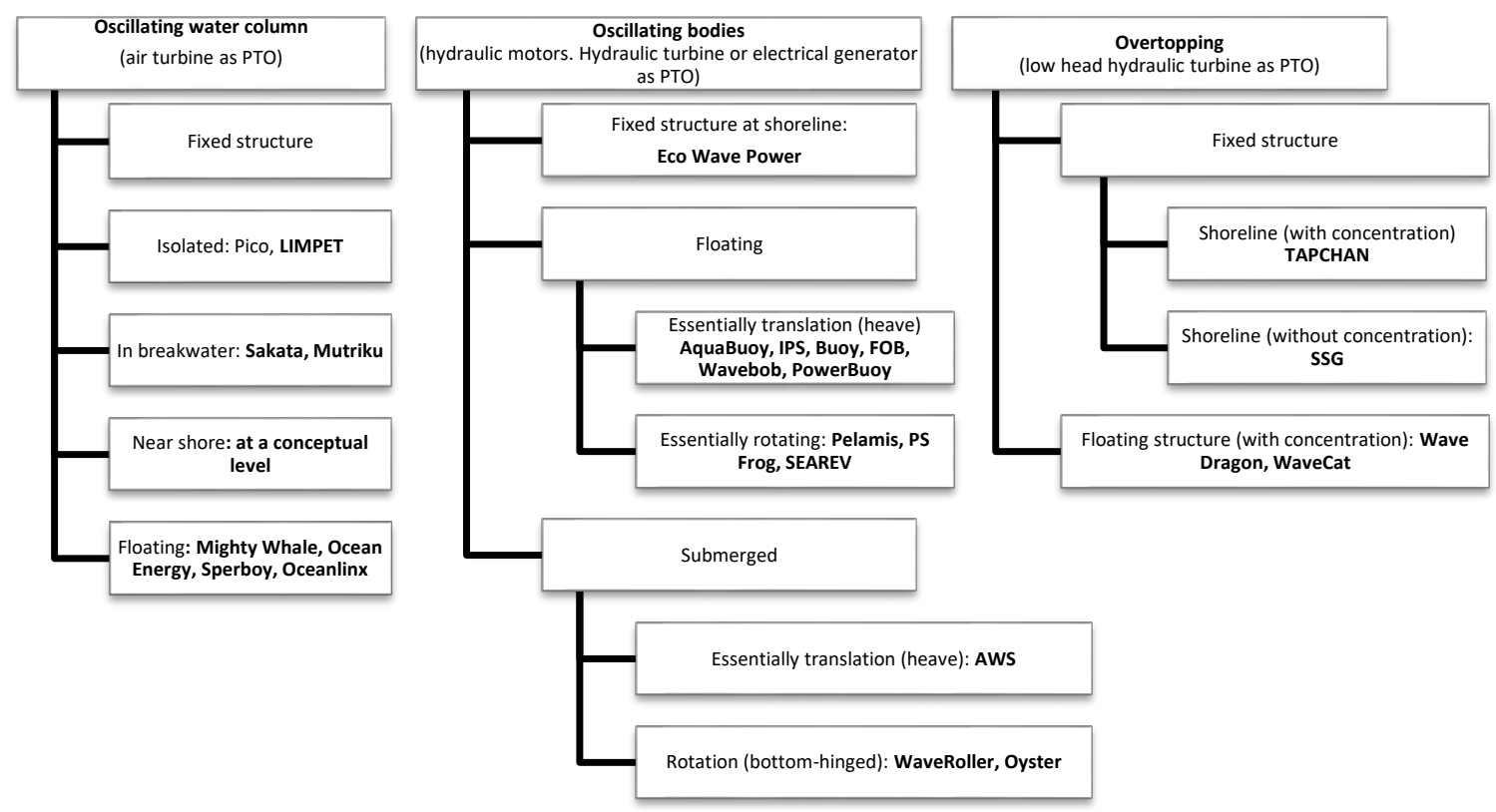

Figure 1Classification of Wave Energy Conversion systems based on recent researches

A typical WEC consists of (1) foundation or mooring keeping the structure and prime mover in place, (2) the structure and prime mover that captures the energy of the wave, (3) the power take-off (PTO) system which converts mechanical energy into electrical energy, and (4) the control systems to safeguard and optimize performance in operating conditions.[10]published an elaborated list of wave energy technologies which Fig. 1 is based on.

Lastly, the power corresponding to the unit length of three-dimensional wave front at a location is simply calculated using Eq. (1)

$\mathrm{P}=\rho \mathrm{gH}^{2} \mathrm{C}_{\mathrm{g}} / 8[\mathrm{~kW}]$

\section{Whereas;}

$\rho$ : is the density of the sea water $\left(\mathrm{kg} / \mathrm{m}^{3}\right), \mathrm{g}$ is gravitational acceleration $\left(\mathrm{m} / \mathrm{sn}^{2}\right), \mathrm{Cg}$ is group velocity $(\mathrm{m} / \mathrm{sn}), \mathrm{H}$ is mean significant wave height $(\mathrm{m})[5]$

\section{Case For Turkey}

Western coasts of the continents in the 40-60 latitude range, both north and south, have the highest energetic ocean waves as they are bigger and more powerful thanks to the prevailing west-to-east winds. In these areas, the annual average power in the wave fronts varies between 30 and $70 \mathrm{~kW} / \mathrm{m}$, peaking up to $100 \mathrm{~kW} / \mathrm{m}$ at some locations. Researchers have shown that countries located at relatively high latitude and having a coastline of ocean immediately to the west have substantial wave power potential [16].

On the other hand, some researchers have reported that the average wave powers acting in unit width in Northeast Atlantic, at coasts of Portugal, in Canada, in South Africa and in China are $100 \mathrm{~kW} / \mathrm{m}, 5-26 \mathrm{~kW} / \mathrm{m}$, $0.6-101.6 \mathrm{~kW} / \mathrm{m}, 10-14 \mathrm{~kW} / \mathrm{m}$ and $0.7-4.5 \mathrm{~kW} / \mathrm{m}$ respectively [9].

The power of the wave fronts at non-oceanic coasts varies between $10-40 \mathrm{~kW} / \mathrm{m}$, and for Mediterranean coasts it is given to be around $13 \mathrm{~kW} / \mathrm{m}$. In measurements made outside of Turkey in the Mediterranean region, this figure varies between $8.4-15.5 \mathrm{~kW} / \mathrm{m}$ throughout the year [1]. 


\subsection{Wave Energy Potential and Situation in Turkey}

Although Turkey does not have coasts to oceans and does not have a long stretch of west coastline the Black Sea basin may offer a good potential for development as an energetic regime, often comparable to oceanic sites in terms of wave heights, is induced by strong wind patterns [16].

Renewable of sea origin available in Turkey; are wave energy, marine temperature gradient energy, sea currents (in the straits of Istanbul and Canakkale) as there is no tidal energy potential in Turkey. Although there are strong sea currents in straits of Canakkale and Istanbul, marine traffic limits making use of this energy.

For Turkey, the most important energy of this group is wave energy and marine wave converters are not arranged in a single row, wave converters are not limited by coastal length. Yet, longer coastline is still a pro. Turkey's coastline is about $8,200 \mathrm{~km}$ excluding coasts of the Sea of Marmara. It is an undeniable fact that Turkey has a great potential of wave energy.

As of the year 1998, in his very precious piece-of-art work, [1] had stated that Turkey had no wave observations and relevant data. He urged that relevant measurements should be made and applications that could be done within the framework of technological possibilities should be sought and complained ofthe absence of institutions or organizations to carry out the work.

At that time, the use of marine wave energy had not yet entered the agenda of Turkey, despite the fact that numerous power plants had already been established around the world. Turkey's estimated total wave power potential was given to be $75.000 \mathrm{MW}$ and wave energy potential was given to be 150 billion $\mathrm{kWh}$ per annum, nevertheless the technical potential was struck through and given as "none" or "not applicable"[1]. But other researchers claim that the technical potential of wave energy that can be harvested by taking utilizing only one-fifth of Turkey's coastline is 18.5 billion kWh [5].

Later, there have been a number of studies on determining the wave energy potential of Turkey. Within the scope of NATO TU WAVE, a project related to Wind Energy, an Atlas of Turkish Coastal Winds and Deep Water Waves was formed.

Figure 2 and Figure 3, taken from this Atlas, show approximate significant wave height $(\mathrm{H})$ and wave period (T) values, and the approximate minimum and maximum levels of wave energy ready for use $[17,18]$.

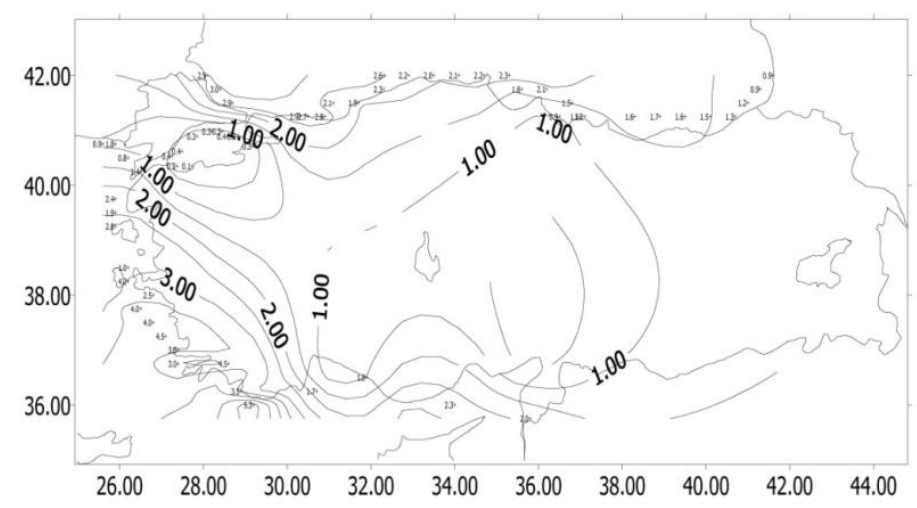

Figure 2.Approximate significant wave height $(\mathrm{H})$ and wave period $(\mathrm{T})$ values 


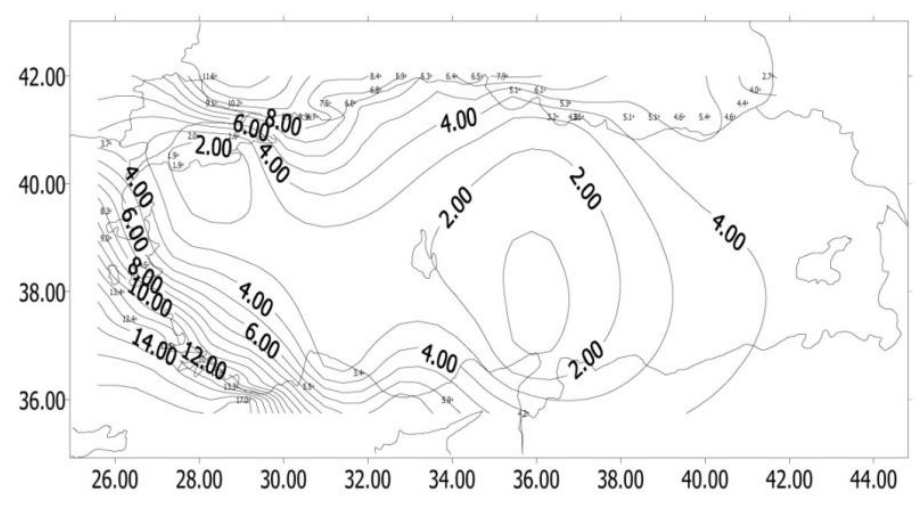

Figure 3.Approximate minimum and maximum levels of wave energy ready for use

In the contrary to the claims that Black Sea is wavier than any other sea surrounding Turkey, the prevailing wind potential in Aegean and Mediterranean seas intensify particularly in the south-western region between İzmir and Antalya, more precisely from Dalaman in west to Finike in east[17,18].

Table 1.Wave intensities as reported by[17,18].

\begin{tabular}{|c|c|}
\hline Region & Wave Intensity \\
\hline İzmir-Antalya & $3.91-12.05 \mathrm{kWh} / \mathrm{m}$ \\
\hline Aegean Sea & $2.86-8.75 \mathrm{kWh} / \mathrm{m}$ \\
\hline Mediterranean & $2.59-8.26 \mathrm{kWh} / \mathrm{m}$ \\
\hline Black Sea & $1.96-4.22 \mathrm{kWh} / \mathrm{m}$ \\
\hline Marmara & $0.31-0.69 \mathrm{kWh} / \mathrm{m}$ \\
\hline
\end{tabular}

[19] have investigated wave energy potential at a total of 7 study points in south-east coast of Black Sea using a third generation wave model, SWAN. The investigation area covers Hopa, Rize, Trabzon, Giresun, Ordu, Samsun and Sinop.

Table 2.Wave energy potential and average wave power findings by [19]

\begin{tabular}{|c|c|c|c|c|c|}
\hline Pointname & $\begin{array}{c}\text { (Hs)mean } \pm \text { std. } \\
\text { dev. } \\
(\mathrm{m})\end{array}$ & $\begin{array}{c}(\mathbf{H s}) \\
\max (\mathrm{m})\end{array}$ & $\begin{array}{c}\text { Jmean } \\
(\mathbf{k W} / \mathbf{m})\end{array}$ & $\underset{(\mathbf{k W} / \mathbf{m})}{\mathbf{J m a x}}$ & $\begin{array}{c}\text { Annual wave } \\
\text { energy } \\
\text { (MWh/m yr) }\end{array}$ \\
\hline Sinop & $0.533 \pm 0.442$ & 4.566 & 1.123 & 83.664 & 9.841 \\
\hline Samsun & $0.399 \pm 0.316$ & 4.295 & 0.524 & 73.333 & 4.592 \\
\hline Ordu & $0.403 \pm 0.365$ & 4.614 & 0.702 & 93.412 & 6.153 \\
\hline Giresun & $0.384 \pm 0.348$ & 4.619 & 0.629 & 97.638 & 5.518 \\
\hline Trabzon & $0.414 \pm 0.372$ & 4.186 & 0.689 & 72.031 & 6.036 \\
\hline Rize & $0.383 \pm 0.358$ & 4.249 & 0.646 & 77.755 & 5.665 \\
\hline Hopa & $0.361 \pm 0.347$ & 3.886 & 0.597 & 64.907 & 5.231 \\
\hline
\end{tabular}

In another study carried out in Çeşme, İzmir, [9] has found that the average wave powers acting in unit width 
varies between $7.16-39.66 \mathrm{~kW} / \mathrm{m}$ with an average of $14.84 \mathrm{~kW} / \mathrm{m}$. This potential suggests that Turkey can compete with other countries in terms of evaluation of wave energy [9].

Both studies shown that WECs with a nominal power of $15 \mathrm{~kW} / \mathrm{m}$ is suitable for Çeşme, and as for South East Black Sea region more than $15 \mathrm{~kW} / \mathrm{m}$ is affordable.

\subsection{Challenges}

There are different assessments of wave energy potential; the amount of available energy as found in the nature is called natural potential, the utilizable amount of natural potential through the instrumentality of practical information and technical capacity we have is called technical potential, and the unit cost of technical potential as compared to that of other energy sources is called economic potential [5]. While natural potential and/or technical potential is important in terms of the diversity in energy supply and non-dependence on foreign sources, economic potential is crucial in financial aspect. Therefore, the major concern must be the economic potential rather than the natural potential.

Period of the waves in the sea varies between 3 to 5 second. The energy which can't be converted into useful work or into another type of energy in the course of this small time span will wither away under effects of successive waves, the buoyancy of the water and gravity. Therefore, selection of WECs is particularly important.

In determination of the nominal power of wave turbines enabling the conversion of wave energy into electrical energy, the current average wave power potential plays the primary role. In electric power generation, the use of turbines having a nominal power greater than available average wave power will result in the excess part of the turbine power remaining idle. While this increases the unit cost of electric energy generated from waves, the contrary, that is the nominal power of the wave turbine is less than the available average, will result in non-utilized wave power, which poses negative impact on the economy of power conversion. Therefore, the average wave power needs to be determined and turbine selection should be done accordingly.

On the other hand, other challenges that need to be overcome and/or bore in Wave Energy Conversion include but not limited to:

- Some devices are susceptible to be destroyed by the forces of tides, waves and strong storms,

- Accessibility, maintenance and repair can also be costly,

- The typical efficiency of a wave energy device at the moment is only about $30 \%$. Waves generate about 2,700 gigawatts of power, only about 500 gigawatts of which can be captured with the current technology.

- There is a potential impact on the marine environment.

- Noise pollution, for example, could have negative impact if not monitored, although the noise and visible impact of each design varies greatly.

$\circ$ The major competitor of wave power is offshore wind power.

- Wave farms can result in the displacement of commercial and recreational fishermen from productive fishing grounds hence lead to a socio-economic challenge.

- Other biophysical impacts (flora and fauna, sediment regimes and water column structure and flows) are being studied [20].

\subsection{Policies and Politics}

In 1998, using Energy Simulation Model (ESM) and Energy Optimization Model (EOM), a 25-years energy production scenario for Turkey, starting from year 2000, has been prepared. 
Table 3. Turkey's domestic primary energy production scenario (in ktoe) for years 2000 to 2025[1].

\begin{tabular}{|l|r|r|r|r|r|r|r|}
\hline \multicolumn{1}{|c|}{ Years } & \multicolumn{1}{c|}{2000} & \multicolumn{1}{c|}{2005} & \multicolumn{1}{c|}{2010} & \multicolumn{1}{c|}{2015} & \multicolumn{1}{c|}{2020} & \multicolumn{1}{c|}{2023} & \multicolumn{1}{c|}{2025} \\
\hline Coal / Lignite / Asphaltite & 18.253 & 23.452 & 28.819 & 35.059 & 42.169 & 46.852 & 51.136 \\
\hline Petrol + Natural Gas & 3.408 & 2.127 & 2.155 & 2.155 & 2.580 & 2.580 & 2.580 \\
\hline Central Heat & 253 & 495 & 884 & 1.336 & 2.018 & 2.427 & 2.748 \\
\hline Hydraulic & 3.763 & 6.268 & 7.695 & 9.219 & 9.989 & 10.726 & 11.585 \\
\hline Nuclear (1st alt.) & - & - & 3.657 & 9.143 & 18.286 & 26.988 & 29.200 \\
\hline Nuclear (2nd alt.) & - & - & 3.657 & 10.972 & 21.943 & 32.386 & 35.040 \\
\hline Geothermal & 432 & 1.380 & 3.760 & 5.000 & 5.250 & 5.400 & 5.400 \\
\hline Solar & 287 & 716 & 1.458 & 2.514 & 3.882 & 4.854 & 5.564 \\
\hline Wind & 58 & 263 & 629 & 995 & 1.519 & 1.883 & 2.167 \\
\hline Sea Wave & - & - & 10 & $\mathbf{2 5}$ & 125 & 175 & 175 \\
\hline Traditional Biomass & 6.963 & 6.461 & 5.734 & 4.789 & 3.980 & 3.560 & 3.307 \\
\hline Modern Biomass & 17 & 765 & 1.652 & 2.500 & 3.515 & 4.049 & 4.406 \\
\hline Total & $\mathbf{3 3 . 4 3 4}$ & $\mathbf{4 1 . 9 5 7}$ & $\mathbf{5 6 . 4 5 3}$ & $\mathbf{7 2 . 7 3 5}$ & $\mathbf{9 3 . 3 1 3}$ & $\mathbf{1 0 9 . 4 9 5}$ & $\mathbf{1 1 8 . 2 6 8}$ \\
\hline
\end{tabular}

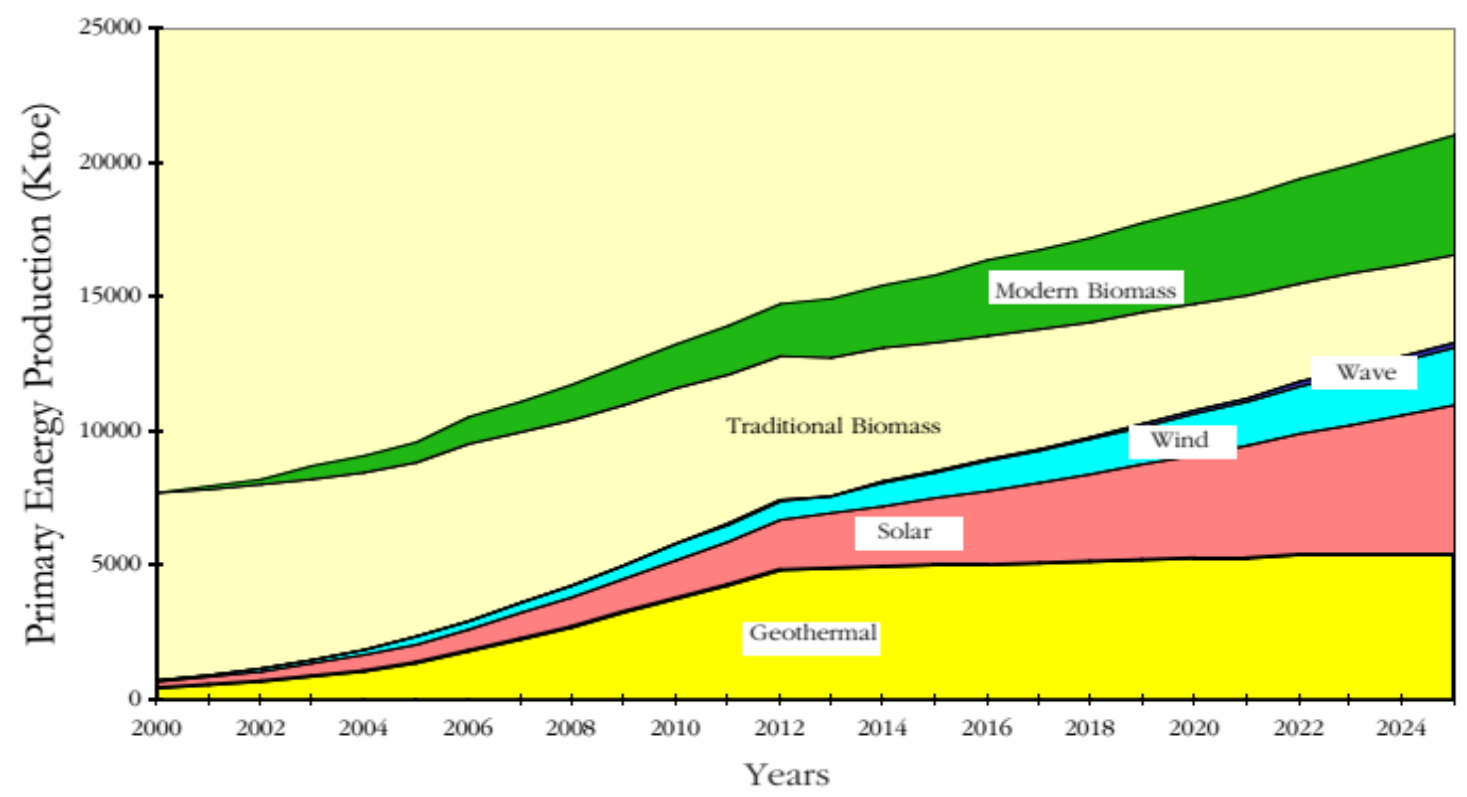

Figure 4: New and renewable energy sources in Turkey's domestic energy production according to the EOM model outputs.

As seen in Table 3 and Figure 4, Wave energy utilization had been in the agenda, and by the year 2010 and 2015, 10 ktoe and 25 ktoe wave energy production had been estimated. Before going any further, let's have a look at the latest National Renewable Energy Action Plan (REAP) published by [21].

In "The Law on the Utilization of Renewable Energy Resources for the Purpose of Generating Electrical Energy" (Law No: 5346), among defined Renewable Energy sources is wave energy. In this action plan optimistic, realistic as well, targets are set and trajectories defined in order to meet the targets. Financial support for the promotion for Tidal/Wave, sea thermal, and marine current energy technologies is said to be 
considered and planned within the scope of REAP. It also states that wave energy has a promising future in Turkey, as the country has an extensive surface and a large coastline, suitable to develop and install WECs.Therefore, financial support for R\&D and the promotion of these technologies will be established. For wave energy, in terms of trajectories, financial support to the investors for the promotion for wave energy technologies is planned, but the launching date is still under consideration. Nevertheless, analyzing the tenyear look-ahead chart for the renewable for electricity generation, under concrete obligations/targets per year (per technology) from year 2013 to 2023, we can see no projection for wave energy. Both installed capacity and electricity generation targets for wave energy is neglected up to the year 2023, as seen in Fig. 5. and Fig.6.

\begin{tabular}{c|c|c|c|c|c|c|}
\hline $\begin{array}{c}\text { Renewable } \\
\text { energy } \\
\text { technology }\end{array}$ & \multicolumn{2}{|c|}{ Installed power capacity (MW) } & \multicolumn{3}{|c|}{ Electricity generation (GWh) } \\
\cline { 2 - 7 } & $\mathbf{2 0 1 3}$ & $\mathbf{2 0 2 3}$ & $\boldsymbol{\Delta}$ & $\mathbf{2 0 1 3}$ & $\mathbf{2 0 2 3}$ & $\boldsymbol{\Delta}$ \\
\hline Hydro & 22,289 & 34,000 & $53 \%$ & 59,420 & 91,800 & $54 \%$ \\
\hline Wind & 2,759 & 20,000 & $625 \%$ & 7,558 & 50,000 & $562 \%$ \\
\hline Geothermal & 310 & 1,000 & $223 \%$ & 1,364 & 5,100 & $274 \%$ \\
\hline Solar & 0 & 5,000 & - & 0 & 8,000 & - \\
\hline Biomass & 224 & 1,000 & $346 \%$ & 1,171 & 4,533 & $287 \%$ \\
\hline
\end{tabular}

Figure 5: Electricity generation and installed capacity: 2013 data, 2023 forecast and increases [21]
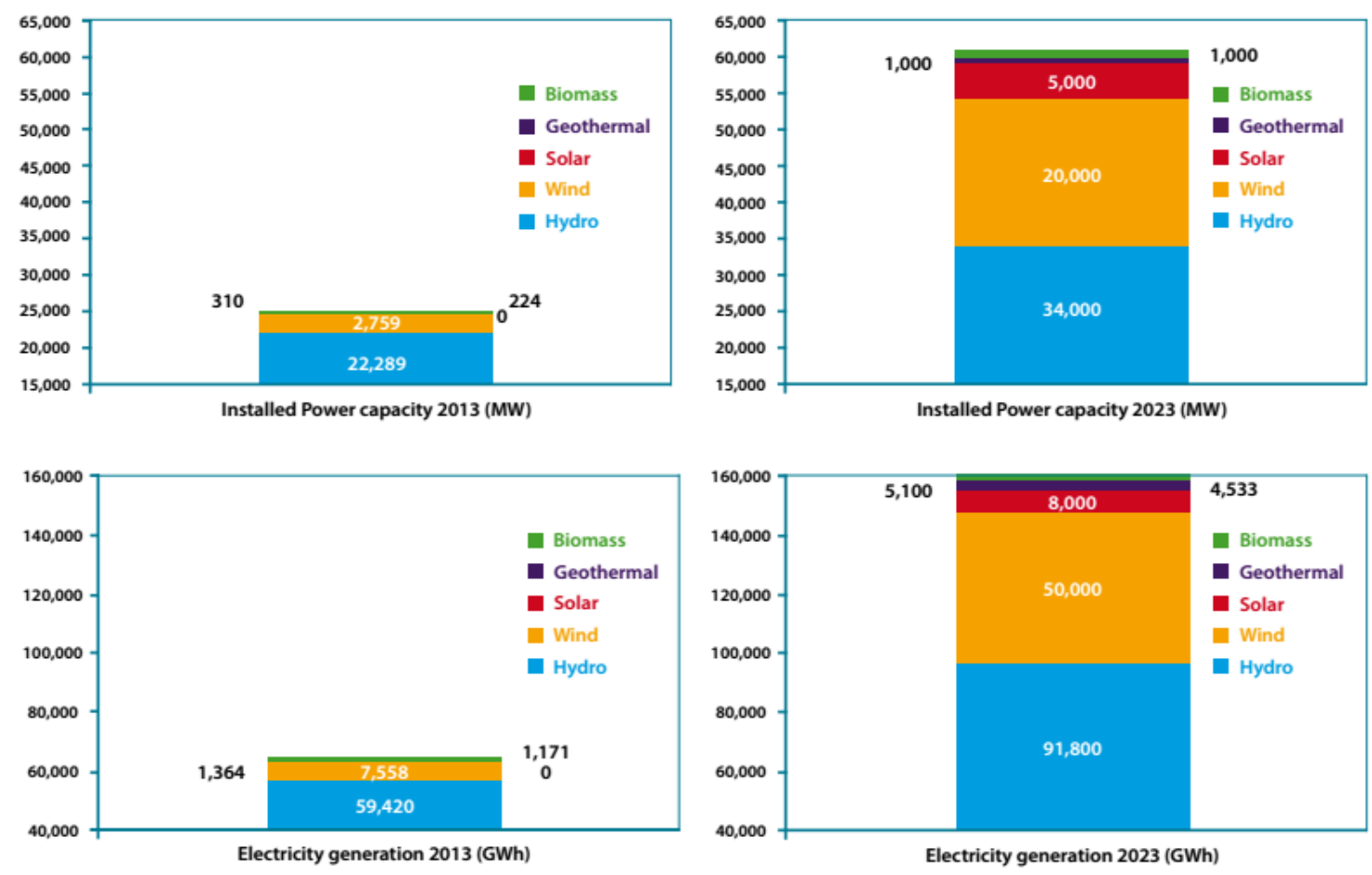

Figure 6: Electricity generation and installed capacity from renewable sources: 2013 data and 2023 forecast

(Ministry of Energy and Natural Sources, Republic of Turkey, 2014)

What made the policy-makers change their mind is unknown, but what is clear is that wave energy seems to have not been in Turkey's agenda at present. 


\section{Discussion}

Among renewable, one with the greatest potential for development and promising for the near future is surely the wave energy. With regards to predictability, high power density, offering relatively high utilization factor, and environmental and visual friendliness; wave energy presents numerous advantages [19].

In terms of environmental sensitivity, wave energy is expected to reduce the dependence on fossil fuels in producing electricity, directly and indirectly. Yet, WECs can be used to produce hydrogen, thus adverse impacts of energy supply may be decreased at a certain level, which in turn help decrease global warming, acid rains, and other contamination in a way[24].

Although many studies have been carried out for the determination of wave energy potential along the shores of the country throughout the last decade, comparative experimental and theoretical studies on selection of appropriate turbine systems to take advantage of available potential in the most economical way is also required. The target on the use of alternative energy sources of Vision 2023, recently declared by the government, is very hard to be met neglecting wave energy, an alternative renewable energy source with a high potential.

Table 4. General Energy Balance for years for Turkey (based on data by MENR)

\begin{tabular}{|r|r|r|r|r|r|r|r|r|}
\hline Year & Hydro & Biomass & Wind & Geothermal & Solar & Total & Ren. Share in Tot. & Hydro share in Ren. \\
\hline $\mathbf{2 0 0 7}$ & $\mathbf{3 2 1 7}$ & $\mathbf{1 2}$ & $\mathbf{3 1}$ & $\mathbf{9 1 4}$ & $\mathbf{4 2 0}$ & $\mathbf{2 7 3 7 3}$ & $\mathbf{1 7 \%}$ & $\mathbf{7 0 \%}$ \\
\hline $\mathbf{2 0 1 4}$ & $\mathbf{3 4 9 5}$ & $\mathbf{8 1}$ & $\mathbf{7 3 3}$ & $\mathbf{3 5 2 4}$ & $\mathbf{8 0 3}$ & $\mathbf{3 1 0 4 9}$ & $\mathbf{2 8 \%}$ & $\mathbf{4 0 \%}$ \\
\hline
\end{tabular}

While the share of renewable energy sources in electricity production reached $17 \%$ in the last decade, more than $70 \%$ of renewable energy-based electricity was supplied from hydropower [22]. As of the year 2014, share of renewable rose to 28 percent while share of hydropower in renewable decreased to $40 \%$ [23]. Other renewable energy sources, with a share of less than $1 \%$, are almost non-utilized in annual total electricity production. Although there are recent investments along with subsidies and incentives on solar-based electricity production projects, majority of new renewable energy investments is focused in wind, solar, biomass and geothermal energy, and so far, wave energy is still not considered.

The most suitable sites for WEC installation and energy production are reported to be the Black Sea, in the north of Istanbul strait and off the southwestern and western coasts in Aegean/Mediterranean region. When coasts not having enough potential for commercialization and other facility sites are excluded, WECs set up at three main regions off the coasts of Turkey, having annual wave power between 3 and $17 \mathrm{~kW} / \mathrm{m}$, would convert a total of around $10 \mathrm{TWh} / \mathrm{year}$, which is $7.8 \%$ of the current economically feasible hydro electrical potential [24].

The characteristics of a WEC should be in conformity with the characteristics of the sea, in other words, the marine conditions and climate of the sea. A WEC perfect for North Sea may not perform as good in a mild climate sea, such as the Mediterranean. The fore an index called Wave Energy Development Index (WEDI) is defined for sites and being used in design and selection phases at the beginning of a project. In light of the findings from researches, the characteristics of Baltic Sea seem to conform to Turkish waters hence devices designed for that sea can be good samples for the studies in Turkey [24].

The Black Sea basin and South-west Mediterranean region, which may often be comparable to oceanic sites in terms of wave heights, are induced by strong wind patterns and may offer a good potential for development as an energetic regime. 


\section{References}

[1] M. Ö. Ültanır, 21. Yüzyıla Girerken Türkiye’nin Enerji Stratejisinin Değerlendirilmesi [Evaluation of Turkey's $21^{\text {st }}$-Century Energy Strategy], Lebib, 1998.

[2] L. H. Holthuijsen, Waves in oceanic and coastal waters, Cambridge University Press, Cambridge, 2007.

[3] D. Mollison, "Wave Climate and the Wave Power Resource," in Hydrodynamics of Ocean WaveEnergy Utilization: IUTAM Symposium Lisbon/Portugal 1985, D. V. Evans and A. F. O. Falcão, Eds., pp. 133-156, Springer Berlin Heidelberg, Berlin, Heidelberg, 1986.

[4] E. Özkop, An Intelligent Controlled Novel Power Conditioning For Wave Energy Converter Systems, Ph.D. Thesis, Karadeniz Technical University, 2012.

[5] İ. Uygur, R. Demirci, H. Saruhan et al., "Batı Karadeniz Bölgesindeki Dalga Enerjisi Potansiyelinin Araştırılması [An Investigation of Wave Energy Potential in Western Black Sea Region]," PAJES Pamukkale University Journal of Engineering Sciences, vol. 12, no. 1, pp. 7-13, 2006.

[6] G. Iglesias and R. Carballo, "Wave energy potential along the Death Coast (Spain)," Energy, vol. 34, no. 11, pp. 1963-1975, 2009.

[7] A. F. d. O. Falcão, "Wave energy utilization: A review of the technologies," Renewable and Sustainable Energy Reviews, vol. 14, no. 3, pp. 899-918, 2010.

[8] A. S. Bahaj, "Generating electricity from the oceans," Renewable and Sustainable Energy Reviews, vol. 15, no. 7, pp. 3399-3416, 2011.

[9] A. Özdamar, "Dalga Enerjisinden Elektrik Enerjisi Eldesi Üzerine Bir Araştırma: Çeşme Örneği [An Investigation on Electricity Generation from Wave Energy: Çeşme Example]," Ege Journal of Fisheries and Aquatic Sciences, vol. 17, 1-2, pp. 201-213, 2000.

[10] International Renewable Energy Agency, "IRENA Ocean Energy Technology Brief 4 June 2014: Wave Energy Technology Brief," 2014.

[11] J. Cruz, Ocean wave energy: Current status and future prepectives [i.e. perspectives], Springer, Berlin, 2008.

[12] A. Okur, Karadeniz Ereğli'de Dalga Enerjisi Üretimine Bir Yaklaşım [An Approach to Wave Energy Conversion in Karadeniz Eregli], Master Thesis, Karaelmas Üniversitesi, 2011.

[13] A. Clément, P. McCullen, A. Falcão et al., "Wave energy in Europe: Current status and perspectives," Renewable and Sustainable Energy Reviews, vol. 6, no. 5, pp. 405-431, 2002.

[14] M. G. Hughes and A. D. Heap, "National-scale wave energy resource assessment for Australia," Renewable Energy, vol. 35, pp. 1783-1791.

[15] C. Perez-Collazo and G. Iglesias, "Integration of Wave Energy Converters and Offshore Windmills," in Conference Proceedings, 2012.

[16] E. Rusu, "Wave energy assessments in the Black Sea," Journal of Marine Science and Technology, vol. 14, no. 3, pp. 359-372, 2009.

[17] E. Özhan and S. Abdalla, Türkiye Kıyıları Rüzgar ve Derin Deniz Dalga Atlası [Atlas of Turkish Coastal Winds and Deep Water Waves], Turkish National Committee on Coastal Zone Management / MEDCOAST, Ankara, 2002.

[18] M. Sağlam and T. S. Uyar, "Wave Energy and Technical Potential of Wave Energy for Turkey," in Conference Proceedings, 2005.

[19] A. Akpınar and M. İ. Kömürcü, "Wave energy potential along the south-east coasts of the Black Sea," Energy, vol. 42, no. 1, pp. 289-302, 2012.

[20] "Wave Energy: Renewable Energy Research," Bluebird Marine Systems, Ltd., http://www.bluebirdelectric.net/wave_power_energy_generation.htm.

[21] "National Renewable Energy Action For Turkey," Ministry of Energy and Natural Sources, Republic of Turkey,

2014 , http://www.eigm.gov.tr/File/?path=ROOT\%2f4\%2fDocuments\%2fEnerji\%20Politikas\%C4\%B1\%2fNa tional_Renewable_Energy_Action_For_Turkey.pdf.

[22] "General Energy Balance for the Year 2007 for Turkey," Ministry of Energy and Natural Resources, Republic of Turkey, 2011, http://www.eigm.gov.tr/File/?path=ROOT\%2f4\%2fDocuments\% 2fDenge+Tablosu\%2f2007 Denge Tablosu.xlsx. 
[23] "General Energy Balance for the Year 2014 for Turkey," Ministry of Energy and Natural Resources, Republic of Turkey, 2016, http://www.eigm.gov.tr/File/?path=ROOT\%2f4\%2fDocuments\%2fSayfalar\%2f2014+Genel+Enerji+De nge+Tablosu.xlsx.

[24] M. Sağlam, E. Sulukan, and T. S. Uyar, "Wave Energy and Technical Potential of Turkey," Journal of Naval Science and Engineering, vol. 6, no. 2, pp. 34-50, 2010.

\section{BIOGRAPHY OF AUTHORS}

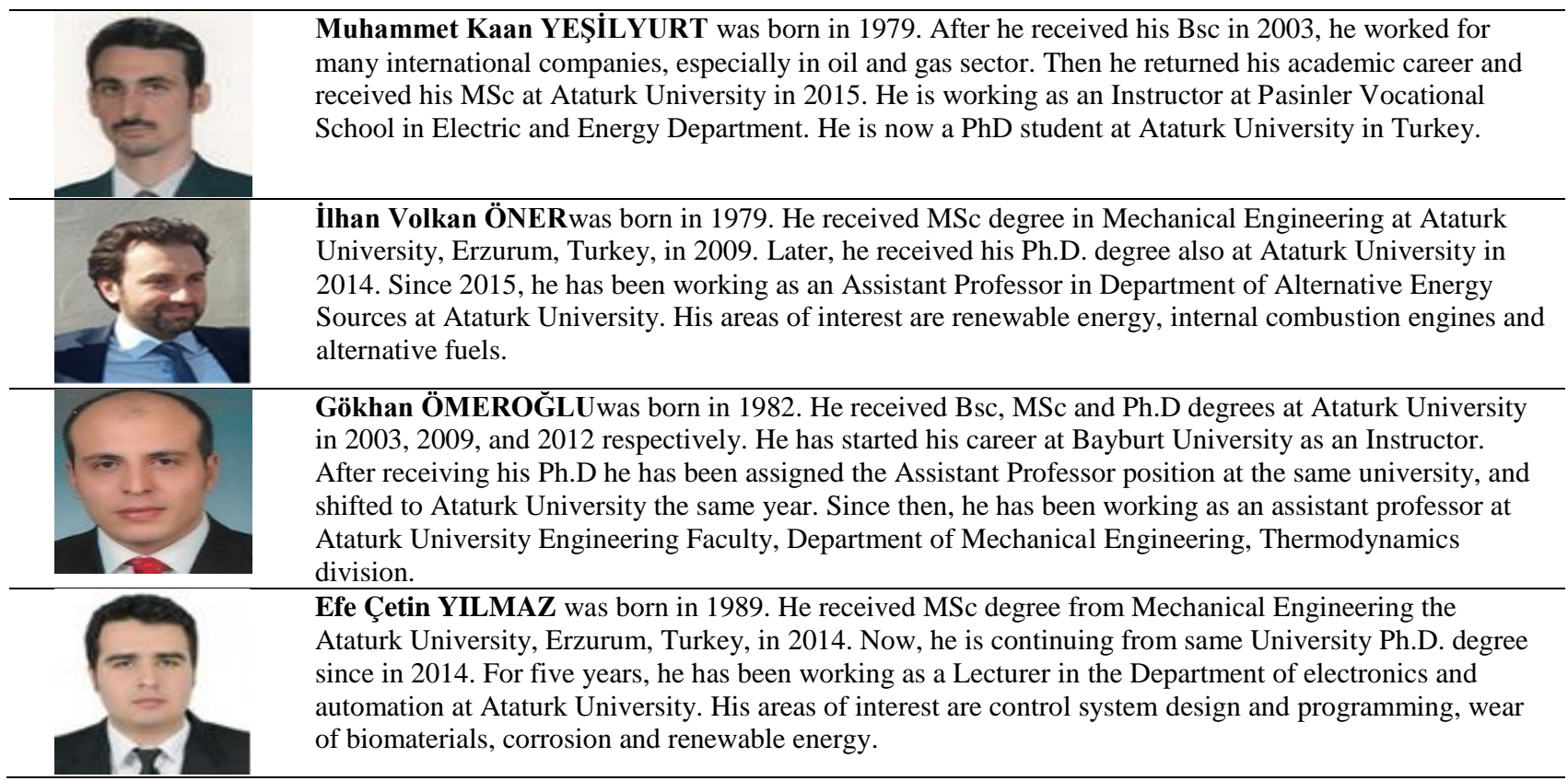

Note:This study has been extended and revised after been presented in 3rd International Conference on Sustainable Development held on 19 - 23 April 2017 in Sarajevo, Bosnia Herzegovina. It was previously published as Abstract in the Book of Abstracts of the conference under the name of "Wave Energy as a Renewable Energy For Turkey". 